\title{
Gender inequality: a comparative study of participation in technical courses
}

\author{
Roslina Masud ${ }^{1}$, Afizah Abdoll Mutalib ${ }^{2}$, Izwah Ismail ${ }^{3}$ \\ ${ }^{123}$ Politeknik Ungku Omar
}

\begin{tabular}{l}
\hline \hline Article Info \\
\hline Article history: \\
Received Dec $2^{\text {st }}, 2018$ \\
Revised Dec $5^{\text {th }}, 2018$ \\
Accepted Dec $11^{\text {th }}, 2018$ \\
\hline
\end{tabular}

Keyword:

Industrial Attachment, Technical Training, Vocational Education, Woman in TVET, Skill for Employability

\section{Corresponding Author:}

Roslina Masud

Politeknik Ungku Omar

Email: masudroslina@gmail.com

\begin{abstract}
Technical Vocational Education Training (TVET) institutions play a crucial role in development of human capital required to transform the developing countries into fully developed nations. The technical skills acquire by the students are led by the industrial needs. However, technical courses are popular among the male students and only a small number of female students enroll into TVET institutions. This paper investigates the gender inequality issues and challenges in TVET education. A comparative study in terms of internship and promotions are included. Consequently, this paper also highlights on the technical and vocational career lines as an alternative pathway for TVET graduates to achieve career success and enhanced social inclusion through higher salaries, job status and educational attainment. The findings indicate that employability of the graduates were related to the individual's strength and organization's ability to appreciate, motivate and support the individuals in their career progression regardless the gender.
\end{abstract}

(C) 2018 The Authors. Published by Redwhitepress.

This is an open access article under the CC BY-NC-SA license

(https://creativecommons.org/licenses/by-nc-sa/4.0/

\section{Introduction}

Recently, issues in TVET had been raised up, where it was stated that TVET is specifically design to supply high skills workers toward entrance into the labor market. The engagement rate between genders found out that women engagement in technical courses in small number compare with men. Consequently, this issues effect the employability rate and increase the gender pay gap in labor market (Fuwa, 2004). The society perception under representation of women with every subsequent iteration in technical courses and the demographic trend in TVET tend to reflect those human capital in the market. Furthermore, the social implications on recruitments for job should be based on skills, experience, aptitude and ability. Both men and women should be treated equal and fair while considering for jobs. Researchers in (Karaca\&Kocabas, 2011) conducted a research to evaluate gender participation in social life using Gender Development Index (GDI) and Gender Empowerment Measure (GEM) for economic life.

Contributing to this study, (Rodgers \& Boyer, 2006) use quantile analysis to examine the gender differences in earnings premiums from TVET education. Singapore's well-developed system of TVET education makes it an ideal country for a comparative study. While the standard ordinary least squares regression approach yields estimates that are performed at the mean of the conditional earnings distribution, quantile regression techniques can produce estimates of the returns to education across the full distribution of earnings. The results indicate that women who have completed TVET education at the tertiary level have done well compared to women with general academic schooling in terms of higher employment rates and a smaller gender earnings gap. Quantile regression results indicate that unlike general academic education, rates of return for vocational education are fairly flat across quantiles, suggesting that TVET education is associated with less inequality in the income distribution compared to general education.

This paper investigates the gender inequality in TVET training program by using evaluation instrument. Based on the review of the literature, author in (Charles \& Bradley, 2002) considered issues of sex segregation in higher education institution. Conceptualization of gender stratification have been presented to describe the relationship 
between modern cultural and structural pressures. The objective of this study is to examine the gender inequality in TVET education system and at the same time efficiently investigate the influence rate of gender inequality in Graduate Employability specifically for technical courses. Limited research has been published on gender discrimination against women for example employees in technical site. Race and sex forms of discrimination are significantly related to negative performance outcomes in the workplace. Consequently, the number of female student's enrollment in technical courses is limited even though no quota set. Therefore, this study has been conducted to examine the factors that lead to gender inequality in technical courses.

Literature in (Gupta, 2017) shows that gender is deeply embedded in organizational thinking and in general, the idea of a universal/ideal worker in organizations is a male unencumbered by familial responsibilities. Furthermore, socio-cultural beliefs and stereotypes form the basis of gendered practices in organizations and cultural differences lead to differences in stereotypes across national contexts .Consequently, through two types of norms and practices: one, norms and practices that favor men and second, socio-cultural norms that devalue women in public spaces which help to maintain masculinity in the workplace. Researcher in (Manic, Joksimovic, \&Zaric, 2018) conducted a pioneering research study of the previously career scale that reneglected problem of the distribution of women in science according to their position. The underrepresentation of women becomes more pronounced with every subsequent iteration along their careers. On the other hand, (Castellano\& Rocca, 2014) were relating the gender gap indexes with country policies frameworks for gender inequalities and the connected policy outcomes. It is possible to evaluate their effectiveness and to identify the most adequate initiatives to undertake because policies reducing gender gaps can significantly improve economic growth and standard of living.

The rest of the paper is organized as follows. Section II describes the methodology used in this study while Section III reserves for the results and findings and Section IV discusses the result of the study of network performance evaluation and finally, Section V summarizes the conclusion and further work.

\section{Method}

The survey was performed in January - April 2018 by distribution of questionnaire among the students to gain their perception about gender gaps in TVET Education. The respondents could use different ways of answering: they could provide answers by email or face-to-face during an interview. The set of question was taken of respondents' personal experience and their individuality providing a detailed and extensive picture of the situation. 13 students with different gender of Institution W (Department of Engineering X and Y) were selected by applying a targeted random sampling. Since there were multiple informative population units, several options have been chosen, and a smaller sample established.

During the data collection period, the scientific literature and documents regulating management, control and changes were analyzed. The research was based on the notion that respondents can use their concepts (words) instead of specific categories which are usually provided in advance. The observation is done on gender Gap in Technical Programs/Courses in Higher Education Institution and analysis on factors and issues within the technical track that effect the gender distribution in technical courses.

In the context of this study, phenomenological research design allowed to analyze personal respondents' experience and get acquainted with the evaluation of the situation. It was considered that the opinion of each respondent was unique and valuable. The following ethical principles were applied during the research: voluntary approach, goodwill, privacy and respect. In order to ensure confidentiality of respondents.

\section{Results}

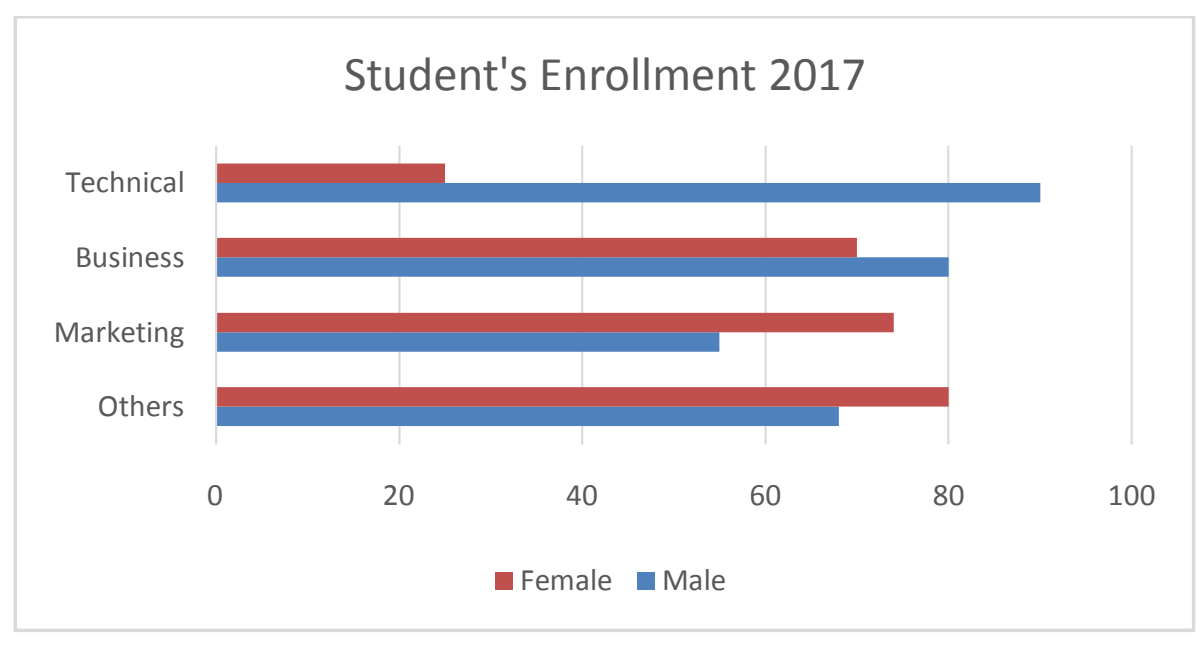


Figure 1 shows the distribution by gender. Gender differences in TVET education are pronounced not only in terms of participation, but also in terms of the distribution of types of study within TVET track. The biggest gender differences occur for the technical courses, which are clearly dominated by male students while the female students dominated in marketing course.

Figure 1:The distribution of student's enrollment by gender in the year of 2017

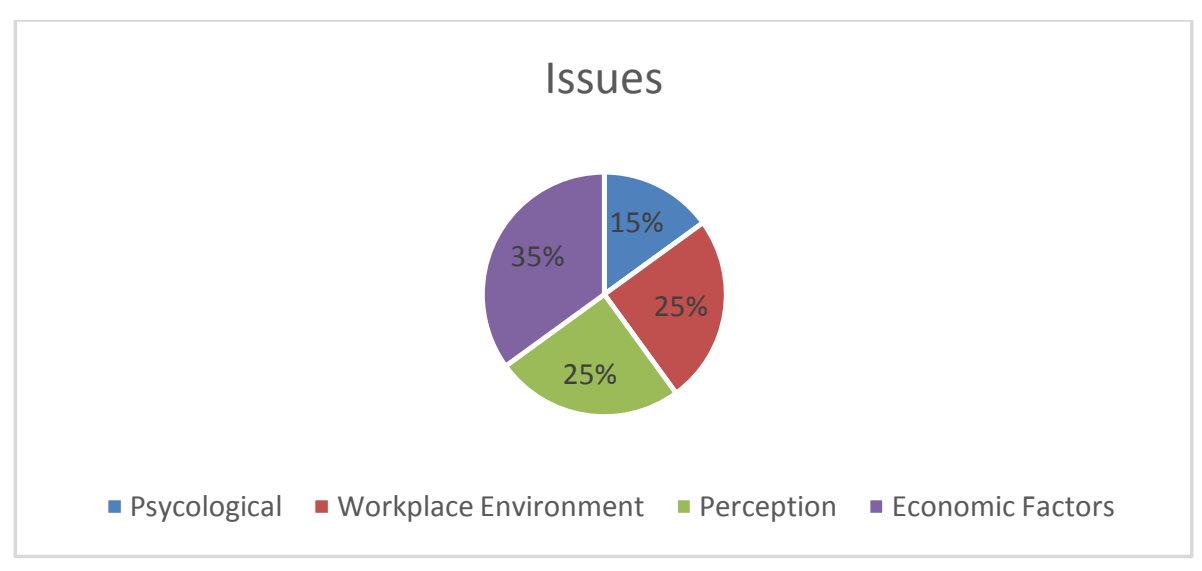

Figure 2 : The Issues of Gender Inequality For Employability

Figure 2 depicts the issues of gender inequality for employability. 15\% of psychological issues due to higher levels of stress, lower self-esteem and less job satisfaction, 25\% of workplace environment where less number of female worker and surrounded by male, $35 \%$ of economic factors where economic constraints in the household significantly influenced gender inequality in the basic education sector while another $25 \%$ of perception that believes that women still do not have fair representation in leadership and decision-making processes.

\section{Discussion}

Results and findings lend weight to the argument that the social gains from workers with TVET education are for male students rather than female students. Critics argue that the training students receive at TVET institution is specific to a certain occupation, while the more general skills that students gain from academic secondary schooling can be transferred across occupations. Another drawback is that students with a TVET background often havemore difficulty getting accepted into a four-year college or university. Hence, critics of TVET education call for a generalization of TVET curricula, with TVET training provided by employers directly in the workplace. A broader range of academic options available to students who graduate from the TVET track would also help to alleviate problems with the vocational college school system. An alternative is for countries to develop their apprenticeship systems, with the argument that apprenticeships help to speed the transition from graduation to finding a job and help to boost training in the workplace without referring to gender. This also stated by (Syamala\& Devi, 2015).

On the other side of the fence, those in favor of TVET education argue that graduates with job-specific skills are potentially more productive in their new jobs and ready to perform the tasks for which they have received training. TVET education can serve as a feasible and effective means for upgrading the skill-set of a workforce and raising the earnings potential of younger cohorts. The conventional wisdom on social rates of return is also disputed. In particular, Bennell (1996) shows that the majority of cost-benefit analyses underlying the conventional wisdom find social rates of return for general education institution that are not significantly higher than rates for TVET education. Further, a number of researchers in this area argue that conventional cost-benefit analyses of in-institution TVET training are conducted in too narrow a framework. Widening the lens to examine, for instance, the earnings of TVET graduates who work in occupations that are matched to their training, yields results showing favorable earnings premiums compared to general academic system as also mentioned by(Stuart \&Quan, 2005). Relative earnings premiums for TVET and general education are also disputed.

\section{Conclusions}

As the conclusion, this finding provide preliminary view for educators to consider several factors in measuring and facing differences across gender, race, and ethnicity in technical vocational education training (TVET). The findings showed a number of policy priorities that contribute to a more inclusive and 
effective approach to TVET education is needed. In particular, the increasing participation of women and minorities in TVET tracks may prepare them for rewarding careers with equal opportunity types of legislation, improved guidance counseling at the secondary school level, the end of sexual harassment, greater choice in countries with education systems based heavily on quotas and standardized tests, and greater incentives for enrollment and retention in nontraditional fields in the TVET track.

The next stage of this research will involve the challenge and resource management scheme to close the gender gap in technical courses and TVET education.

\section{Acknowledgments}

The authors would like to thanks the institution and those parties whoinvolved directly or indirectlyfor their support and assistance given to the authors in carrying out this research study.

\section{References}

Castellano, R., \& Rocca, A. (2014). Gender gap and labour market participation : A composite indicator for the ranking of European countries. International Journal of Manpower, 35(3), 345-367. http://doi.org/10.1108/IJM-07-2012-0107

Charles, M., \& Bradley, K. (2002). Equal but separate ? A cross-national study of sex segregation in higher education. American Sociology Review, 67(2), 573-599.

Fuwa, M. (2004). Macro-level Gender Inequality and the Division of Household Labor in 22 Countries. American Sociology Review, 69(6), 751-767.

Gupta, N. (2017). Gender inequality in the work environment : a study of private research organizations in India. Equality, Diversity and Inclusion : An International Journal, 36(3), 255-276. http://doi.org/10.1108/EDI04-2016-0029

Karaca, N. G., \& Kocabas, F. (2011). The Position of Women in Social and Economic Life : A Comparison Between the EU and Turkey. Eurasian Economic Review, 1, 66-94.

Manic, S., Joksimovic, L., \& Zaric, S. (2018). Vertical Segregation In Higher Education - The Case Study Of The Republic Of Serbia. Economic Horizon, 20(1), 3-14. http://doi.org/10.5937/ekonhor1801003M

Rodgers, Y. V. D. M., \& Boyer, T. (2006). Gender and racial differences in vocational education : an international perspective. International Journal of Manpower, 27(4), 308-320. http://doi.org/10.1108/01437720610679188

Stuart, D., \& Quan, J. J. (2005). Assessing Gender Differences in Software Developers Using the Human Capital Model. Information Resources Management Journal, 18(3), 68-87.

Syamala, G., \& Devi, R. T. (2015). A Study of Gender Discrimination at Campus Recruitment in the Professional Colleges. Journal of Commerce \& Management Thought, 6(2), 323-339. 